in this study. The data were collated as part of an initiative on HTLV infection and disease in Europe supported by the European Community Biomed Programme (CT 98-3781).

Funding: None.

Competing interests: None declared.

Contributors: GPT and JHCT designed and performed the study. RST and PPM provided the diagnostic services. All the authors contributed to the writing of the paper. GPT will act as guarantor

1 International Agency for Research on Cancer. Human immunodeficiency viruses and human T-cell lymphotrophic viruses. Lyons: IARC, 1996. (IARC Monographs on the Evaluation of Carcinogenic Risk to Humans, Vol 67.)
2 Kaplan JE, Osame M, Kubota H, Igata I, Nishitani H, Maeda Y, et al. The risk of development of HTLV-I associated myelopathy/tropical spastic paraparesis among persons infected with HTLV-I. J Acquir Immun Defic Syndr 1990;3:1096-101.

3 Simms I, Tosswill JHC, Noone A, Morgan D. Surveillance of HTLV infection in England and Wales: 1986-1992. Commun Dis Rep CDR Rev 1994:4:R65-9.

4 Haskey J. Population review. 8: The ethnic minority and overseas-born populations of Great Britain. Popul Trends 1997;88:13-30.

5 Tynell E, Andersson S, Lithander E, Arneborn M, Blomberg J, Hansson $\mathrm{HB}$, et al. Screening for human T-cell leukaemia/lymphoma virus among blood donors in Sweden; cost effectiveness analysis. BMJ 1998;316: $1417-22$

(Accepted 14 October 1999)

\title{
Bullying in school: are short pupils at risk? Questionnaire study in a cohort
}

\author{
Linda D Voss, Jean Mulligan
}

University Child

Health,

Southampton

General Hospital,

Southampton

SO21 16YD

Linda D Voss

senior research fellow

Jean Mulligan

data manager

Correspondence to: L D Voss

linda.voss@phnt.

swest.nhs.uk

BMJ 2000;320:612-3
Bullying is still prevalent in schools and is clearly stressful for victims. ${ }^{12}$ It may also have undesirable consequences for bullies, with antisocial behaviour persisting into adulthood. Victims are generally reported to be weaker than the bullies. ${ }^{23}$ This would suggest that very short pupils are more likely to be victims and less likely to be the aggressors. The Wessex growth study allowed us to examine the prevalence of bullying, as experienced or perpetrated by pupils of different heights.

\section{Subjects, methods, and results}

Ninety two short normal adolescents who had been below the third centile for height at school entry ${ }^{4}$ and 117 controls matched for age and sex completed a bullying questionnaire, derived from work by Whitney and Smith. ${ }^{5}$ There were no refusals or any significant differences in sex or social class between the groups. Mean age (range) was 14.7 (13.4-15.7) years. Mean height SD scores were: short pupils -1.90 (-3.53 to -0.01), controls 0.31 (-1.41 to 2.15). Additional data on bullying, collected the previous year, were available from teachers' written reports and parental interviews.

The table summarises the data. More short pupils than controls claimed to have been bullied at some time in secondary school. This difference remained significant after logistic regression controlled for social class. Short boys were more than twice as likely as control boys to be victims and much more likely than control boys to say that bullying upset them. Significantly more short pupils than controls said that bullying had started in junior school. Short pupils had as many good friends as did controls (72/92 (78\%) v $95 / 117(81 \%))$, but significantly more spent break time alone at least once a week (9/92 (10\%) v 2/117 (2\%), $\mathrm{P}=0.032$ ). In many cases bullying had stopped, but significantly more short pupils than controls, regardless of sex, reported current bullying.

Teachers also reported that significantly more short pupils than controls were victims of bullying. Parents reported more bullying, generally, than either teachers or pupils, and parents of controls were as likely as parents of short children to say that their children were bullied. According to teachers, bullies were to be found in both height groups, but whereas significantly fewer control girls than control boys were bullies, short girls were as likely to be bullies as both short and control boys.

\section{Comment}

This report suggests that short children are more likely to be bullied than their taller peers. More short pupils also report a degree of social isolation-the result, or possibly even the cause, of their victimisation. These data are important since the Wessex growth study has previously found few significant psychosocial prob-

Numbers of victims of bullying and bullies among short pupils and controls of average stature (pupils', parents', and teachers' reports). Figures are numbers (percentages) of respondents

Short pupils $(n=92) \quad$ Controls $(n=117) \quad P$ value

Pupils' report
Victim of bullying in secondary school:

\begin{tabular}{cccc}
\hline Total & $42(46)$ & $30(26)$ & $0.003^{* *}$ \\
\hline Boys & $25(46)$ & $13(21)$ & $0.005^{\text {* }}$ \\
\hline Girls & $17(45)$ & $17(32)$ & 0.273 \\
\hline Bullied in both junior and secondary schools: & & \\
\hline Total & $24(26)$ & $13(11)$ & $0.018^{*}$ \\
\hline Boys & $14(26)$ & $4(7)$ & $0.013^{*}$ \\
\hline Girls & $10(26)$ & $9(17)$ & 0.526 \\
\hline
\end{tabular}

Bullying currently

Total $21(23) \quad 4(4)<0.001^{\text {** }}$

\begin{tabular}{llll}
\hline Boys & $11(21)$ & $4(4)$ & $<0.001 *$ \\
\hline
\end{tabular}

Girls $10(26$

$2(4)$
$0.003^{* *}$

upset when bullied:

\begin{tabular}{cccc}
\hline Total & $31(76)$ & $16(55)$ & 0.120 \\
\hline Boys & $17(71)$ & $3(25)$ & $0.014^{*}$ \\
\hline Girls & $14(82)$ & $13(77)$ & 1.000 \\
\hline Parents' report & $\mathrm{n}=88$ & $\mathrm{n}=116$ &
\end{tabular}

Parents' report $\quad \mathrm{n}=88$

\begin{tabular}{lccc}
\hline Total & $37(43)$ & $44(38)$ & 0.605 \\
\hline Boys & $24(46)$ & $25(39)$ & 0.562 \\
\hline Girls & $13(37)$ & $19(37)$ & 1.000 \\
\hline Teachers' report & $\mathrm{n}=84$ & $\mathrm{n}=103$ & \\
\hline Victim of bullying in secondary school: & & \\
\hline Total & $31(37)$ & $23(23)$ & $0.047^{*}$ \\
\hline Boys & $17(36)$ & $12(23)$ & 0.227 \\
\hline Girls & $14(38)$ & $11(22)$ & 0.169 \\
\hline Bullies others in secondary school: & & \\
\hline Total & $13(16)$ & $16(16)$ & 1.000 \\
\hline Boys & $6(13)$ & $13(25)$ & 0.234 \\
\hline Girls & $7(18)$ & $3(6)$ & 0.093 \\
\hline
\end{tabular}

${ }^{*} \mathrm{P}<0.05,{ }^{*} \mathrm{P}<0.01\left(\chi^{2}\right.$ test $)$ 
lems that could be attributed to short stature. The data need, however, to be interpreted with caution: it is possible that shorter pupils are simply more likely to mistake the normal rough and tumble in the playground for bullying. The data could also be accounted for by the fact that significantly fewer control than short boys admitted to being bullied. Even when they did, few confessed to being upset.

Around one in four short victims, girls as well as boys, were both victims and bullies; from the reported association between bullying, physical size, and sex, it might have been expected that few short pupils and even fewer short girls would bully others. ${ }^{13}$ Are some of these the so called provocative victims for whom any reaction, however painful, is preferable to being ignored? $?^{3}$ Pupils do not always tell parents or teachers when they are being bullied, and this report may serve to alert parents and teachers to potential bullies as well as victims. As Olweus reminds us, "Every individual should have the right to be spared oppression and repeated, intentional humiliation, in school as in society at large."
We thank Drs A D Roberts and R Stratford, department of psychology, and Dr R Pickering, department of medical statistics and computing, University of Southampton, for their help and advice and Bruce Downie for interviewing all the parents.

Contributors: LDV designed the protocol, revised and administered the questionnaires, and wrote the paper.JM carried out the statistical analysis and contributed to the interpretation of the results. LDV will act as guarantor for the paper.

Funding: The Wessex growth study has been supported by a research and development grant from the South and West regional office of the NHS Executive and by a grant from the Child Research Fund, Liverpool, and see below.

Competing interests: The Wessex growth study has been supported by a grant from Pharmacia Upjohn to the Wessex Medical Trust.

Salmon G. Bullying in schools: self reported anxiety, depression, and self esteem in secondary school pupils. BMJ 1998;317:924-5.

2 Leff S. Bullied children are picked on for their vulnerability. $B M$ J 1999;318:1076.

3 Olweus D. Bullying at school: what we know and what we can do. Oxford: Blackwell, 1993.

4 Voss LD, Walker J, Lunt H, Wilkin T, Betts PR. The Wessex growth study: first report. Acta Paediatr Scand (suppl) 1989;349:65-72.

5 Whitney I, Smith PK. A survey of the nature and extent of bullying in junior/middle and secondary schools. Educational Research 1993;35:3-25. (Accepted 1 November)

\section{Drug points}

\section{Hypersensitivity reaction to balsalazide}

V Adhiyaman, A Vaishnavi, S Froese, Withybush General Hospital, Haverfordwest, Pembrokeshire SA61 2PZ

Balsalazide is used in short term and maintenance treatment of ulcerative colitis. It is a prodrug in which 5-aminosalicylic acid is linked via a diazo bond to 4 -aminobenzoyl- $\beta$-alanine, an inert and biologically inactive carrier molecule. We report a case of a hypersensitivity reaction to balsalazide, with pericarditis, an abnormal liver biochemistry profile, and splinter haemorrhages.

A 59 year old woman developed indeterminate patchy pancolitis. She was unable to take mesalazine or olsalazine but had no adverse effects with sulphasalazine $1 \mathrm{~g}$ twice daily, which she took as maintenance treatment. Eight months later her symptoms had resolved and she had normal results for inflammatory markers. On request sulphasalazine was discontinued and she started balsalazide $2.25 \mathrm{~g}$ three times daily.

Eight days later she was admitted with central chest pain, shortness of breath, and back pain, which gradually worsened over 3 days. The colitis was still in remission. On examination she was apyrexial, had splinter haemorrhages on two fingernails, and had a raised jugular venous pressure. She had a loud pericardial rub, but there were no murmurs, and the lungs were clear. A soft tender liver was just palpable. Optic fundi were normal.

Investigations showed grossly increased values for inflammatory markers (erythrocyte sedimentation rate $122 \mathrm{~mm}$ for first hour, $\mathrm{C}$ reactive protein concentration $251 \mathrm{mg} / \mathrm{l}$ ) with a mild normocytic anaemia and thrombocytosis. A liver biochemistry profile was indicative of cholestasis (alkaline phosphatase 472 IU/1, $\gamma$-glutamyl transferase $295 \mathrm{IU} / 1$, alanine aminotransferase $50 \mathrm{U} / 1$, and bilirubin $15 \mu \mathrm{mol} / \mathrm{l})$. An electrocardiogram was suggestive of pericarditis, and an echocardiogram showed a small pericardial effusion. Ultrasound of the liver and biliary tree was unremarkable. Multiple blood cultures and paired viral serology gave negative results. Results for autoantibodies including antinuclear factor, cytoskeletal antibodies, and antineutrophil cytoplasm antibody were negative.

Balsalazide was stopped while the results of investigations to exclude an infective or autoimmune cause were awaited. The patient was given non-steroidal antiinflammatory drugs, with some improvement of symptoms and reduction in concentration of acute phase reactants. The chest pain and pericardial rub persisted, however, and she was given prednisolone $20 \mathrm{mg}$ once daily, reduced by $5 \mathrm{mg}$ fortnightly. Symptoms and abnormal blood test results completely resolved within a month, and the steroids were discontinued.

Sulphasalazine was successfully reintroduced, and the patient has remained well. We believe the acute pericarditis, cholestatic liver biochemistry profile, and vasculitis resulted from hypersensitivity to balsalazide because the symptoms developed acutely and other causes were excluded by appropriate tests.

We believe this is the first report of a hypersensitivity reaction to balsalazide: the Committee on Safety of Medicines has received no such notifications, and a search of Medline (1990-9) revealed no cases.

This case has similarities to those of mesalazine associated pericarditis, ${ }^{1}$ pericardial effusion, ${ }^{2}$ and lupus-like syndrome. ${ }^{3}$ Pericarditis associated with sulphasalazine induced lupus syndrome has been recognised ${ }^{45}$ and was previously ascribed to the sulphapyridine moiety. However, similar reactions with 5-acetylsalicylic acid drugs such as mesalazine, which do not contain the sulpha group, suggest that an adverse reaction may be a consequence of the 5 -acetylsalicylic acid molecule. Because the patient reacted to balsalazide but not sulphasalazine the hypersensitivity reaction may have been to the whole drug rather than the sulphapyridine moiety alone.

1 Habal FM, Greenberg GR. Treatment of ulcerative colitis with oral 5-ASA including patients with adverse reactions to sulphasalazine. Am J Gastroenterol 1990;83:15-9.

2 Jenss H, Becker EW, Weber P. Pericardial effusion during treatment with 5-aminosalicylic acid in a patient with Crohn's disease. Am J Gastroenterol 1990:85:332-3.

3 Dent MT, Ganapathy S, Holdsworth CD, Channer KC. Mesalazine induced lupus-like syndrome. BMJ 1992;305:159.

4 Griffiths ID, Kane SP. Sulphasalazine induced lupus syndrome in ulcerative colitis. BMJ 1977;ii:1188-9.

5 Deboever G, Devogelaere R, Holvoet G. Sulphasalazine induced lupus like syndrome with cardiac tamponade in a patient with ulcerative colitis. Am J Gastroenterol 1989;84:85-6. 